\title{
Perception of Community
Conviction in Nueva Ecija
}

\section{Mary Chris Austria-Cruz}

Assistant Professor, College of Management and Business Technology, Sumacab Campus, Nueva Ecija University of Science and Technology, Nueva Ecija, Philippines

maria_cristi@yahoo.com/marychrisaustria@neust.edu.ph

\begin{abstract}
Many known cases of wrongful conviction arose from a burden on law enforcement officials to settle the case either because it is high-profile, or due to financial or other systemic considerations. The study described the perception of the community towards the causes of wrongful conviction and effects of wrongful conviction to the community. This study used the descriptive method. A total of 100 respondents composed of different professionals were surveyed in the study. The researcher used likert-scale responses on the distributed questionnaire and analyze the data through frequency count and percentage. From the data gathered, the researcher concluded that the main reason of wrongful conviction is poverty as perceived by the community garnered the highest frequency count and percentage of being strongly agreed. Further, greater fear topped the effects of the wrongful conviction as perceived by the community garnered the highest frequency count and percentage of being strongly agreed. In the foregoing conclusions, the researcher derived that wrongful conviction has a cognitive and emotional impact to the community's perception. It is recommended that possible attitudes of citizens in wrongful conviction should be conducted in an oral interview instead of survey for more specific and defined answer.
\end{abstract}

Keywords-Conviction, Wrongful Conviction, Poverty, Fear.

\section{INTRODUCTION}

Many known cases of wrongful conviction arose from a burden on law enforcement officials to settle the case either because it is high-profile, or due to financial or other systemic considerations. Risinger (2006) stated that criminal justice system seldom convicts those who are in fact innocent and those who believe that such miscarriages are rife.

Further, Garoupa and Rizzoli (2012) explained that wrong acquittals increase the expected pay-offs of committing crime, but wrongful convictions, on the other hand, reduce the expected payoffs of being real.

Leo and Gould (2009) concluded that wrongful convictions cry out for change and mitigation as there is no greater systematic mistake in the criminal justice systemwhich is triggered by the criminal justice system itself-than a factually innocent person's wrongdoing. The opportunity as Findley (2001) concluded is a significant one - for the wrongly convicted or charged, for the victims who are entitled to know the truth about their offenders, and for community safety.

Huff and Killias (2012) recommended that the frequency of wrongful conviction can be reduced by improving understanding of the structural, organizational, and human causes of error in our justice systems.

\section{CONCEPTUAL FRAMEWORK}

According to Lando (2006), wrong conviction reduces dissuasion by lowering the pay-off to remain innocent, and consequently the view fails to recognize that both the guilty and the innocent can be convicted of criminal acts committed by others.

Ramsey and Frank (2007) concluded that eyewitness mistake, defective evidence, professional incompetence and abuse, unreliable testimony, jumps to judgement, and presumption of guilt are the most frequently mentioned causes of wrongful conviction in the study.

On the contrary, Cole (2006) found out that the phenomenon of wrongful conviction itself, both the prevalence and the potential causes of wrongful conviction by fingerprints remain ultimately obscure. 


\section{OBJECTIVES OF THE STUDY}

The study described the perception of the community towards the causes of wrongful conviction and effects of wrongful conviction to the community.

\section{METHODOLOGY}

This study used the descriptive method. The researchers used the liker-scale to determine perception or view of the respondents regarding this topic. Descriptive Method is designed for the researcher to gather information about presenting existing conditions and to describe the nature of the situation as it exists at the time of the study and to explore the causes of particular phenomena (Camic et al., 2003). A total of 100 respondents composed of different professionals were surveyed in the study. The researcher used likert-scale responses (Vagias, 2006) on the distributed questionnaire and analyze the data through frequency count and percentage.

\section{RESULTS}

Table 1. Perception of Community towards the Causes of Wrongful Conviction

\begin{tabular}{|l|c|c|c|c|c|c|c|c|c|c|}
\hline & \multicolumn{3}{|c|}{ Frequency } & \multicolumn{4}{|c|}{ Percentage } \\
\hline Causes of Wrongful Conviction & $\mathbf{5}$ & $\mathbf{4}$ & $\mathbf{3}$ & $\mathbf{2}$ & $\mathbf{1}$ & $\mathbf{5}$ & $\mathbf{4}$ & $\mathbf{3}$ & $\mathbf{2}$ & $\mathbf{1}$ \\
\hline 1. Poverty & 61 & 29 & 0 & 4 & 6 & $61 \%$ & $29 \%$ & $0 \%$ & $4 \%$ & $6 \%$ \\
\hline 2. Eyewitness Misidentification. & 52 & 37 & 2 & 6 & 3 & $52 \%$ & $37 \%$ & $2 \%$ & $6 \%$ & $3 \%$ \\
\hline 3. False Confession/Admission. & 42 & 43 & 6 & 3 & 6 & $42 \%$ & $43 \%$ & $6 \%$ & $3 \%$ & $6 \%$ \\
\hline 4. Police and Lawyers behavior. & 57 & 31 & 9 & 0 & 3 & $57 \%$ & $31 \%$ & $9 \%$ & $0 \%$ & $3 \%$ \\
\hline 5. Miscarriage of Justice. & 58 & 29 & 3 & 3 & 7 & $58 \%$ & $29 \%$ & $3 \%$ & $3 \%$ & $7 \%$ \\
\hline 6. Misinterpretation of Law. & 50 & 31 & 6 & 4 & 9 & $50 \%$ & $31 \%$ & $6 \%$ & $4 \%$ & $9 \%$ \\
\hline 7. Un-validated/improper Forensic. & 43 & 35 & 13 & 4 & 5 & $43 \%$ & $35 \%$ & $13 \%$ & $4 \%$ & $5 \%$ \\
\hline 8. Informants / Snitches. & 25 & 57 & 13 & 1 & 4 & $25 \%$ & $57 \%$ & $13 \%$ & $1 \%$ & $4 \%$ \\
\hline 9. Witness substantially changes their description of a & 27 & 55 & 14 & 1 & 3 & $27 \%$ & $55 \%$ & $14 \%$ & $1 \%$ & $3 \%$ \\
\hline $\begin{array}{l}\text { perpetrator after they learned more about a particular } \\
\text { suspect. }\end{array}$ & & & & & & & & & \\
\hline 10. Social group Discrimination. & 39 & 44 & 7 & 3 & 7 & $39 \%$ & $44 \%$ & $7 \%$ & $3 \%$ & $7 \%$ \\
\hline 11. Justice Delayed/Justice Denied. & 54 & 33 & 4 & 2 & 7 & $54 \%$ & $33 \%$ & $4 \%$ & $2 \%$ & $7 \%$ \\
\hline 12. Misinterpretation of justice. & 43 & 36 & 13 & 1 & 7 & $43 \%$ & $36 \%$ & $13 \%$ & $1 \%$ & $7 \%$ \\
\hline 13. Influences by government officials. & 50 & 26 & 14 & 1 & 9 & $50 \%$ & $26 \%$ & $14 \%$ & $1 \%$ & $9 \%$ \\
\hline 14. Wrong Implication of judgment. & 58 & 30 & 4 & 5 & 3 & $58 \%$ & $30 \%$ & $4 \%$ & $5 \%$ & $3 \%$ \\
\hline 15. "Kababayan" system. & 38 & 52 & 2 & 4 & 4 & $38 \%$ & $52 \%$ & $2 \%$ & $4 \%$ & $4 \%$ \\
\hline 16. Public Trial & 24 & 50 & 5 & 4 & 17 & $24 \%$ & $50 \%$ & $5 \%$ & $4 \%$ & $17 \%$ \\
\hline 17. Grave abuse of authority & 44 & 29 & 15 & 3 & 9 & $44 \%$ & $29 \%$ & $15 \%$ & $3 \%$ & $9 \%$ \\
\hline 18. Political Influence & 44 & 36 & 14 & 3 & 3 & $44 \%$ & $36 \%$ & $14 \%$ & $3 \%$ & $3 \%$ \\
\hline 19. Interference of three branches of government. & 26 & 48 & 18 & 1 & 7 & $26 \%$ & $48 \%$ & $18 \%$ & $1 \%$ & $7 \%$ \\
\hline
\end{tabular}

*Multiple Responses

Legend:

$\begin{array}{lll}1 & - & \text { Strongly Disagree } \\ 2 & - & \text { Disagree } \\ 3 & - & \text { Neutral }\end{array}$

$\begin{array}{lll}4 & - & \text { Agree } \\ 5 & - & \text { Strongly Agree }\end{array}$

Table 1 presents the causes of the wrongful conviction. The cause "poverty" got the highest frequency count of 61 out of 100 garnering $61 \%$ of being rated " 5 " that implies that majority of the respondents strongly agreed that this is the

main cause of wrongful conviction. Thus, the cause "public trial" got the highest frequency count of 17 out of 100 garnering $17 \%$ of being rated " 1 " that implies that majority of 
the respondents strongly disagreed that this is a cause of wrongful conviction.

Table 2. Effects of Wrongful Conviction to the Community

\begin{tabular}{|l|l|l|l|l|l|l|l|l|l|l|l|}
\hline & \multicolumn{5}{|c|}{ Frequency } & \multicolumn{5}{|c|}{ Percentage } \\
\hline & $\mathbf{5}$ & $\mathbf{4}$ & $\mathbf{3}$ & $\mathbf{2}$ & $\mathbf{1}$ & $\mathbf{5}$ & $\mathbf{4}$ & $\mathbf{3}$ & $\mathbf{2}$ & $\mathbf{1}$ \\
\hline $\begin{array}{l}\text { 1. } \\
\begin{array}{l}\text { Greater fear because criminal is } \\
\text { not apprehended. }\end{array}\end{array}$ & 68 & 21 & 4 & 2 & 5 & $68 \%$ & $21 \%$ & $4 \%$ & $2 \%$ & $5 \%$ \\
\hline $\begin{array}{l}\text { Wondering why wrong } \\
\text { conviction happen. }\end{array}$ & 34 & 57 & 4 & 0 & 5 & $34 \%$ & $57 \%$ & $4 \%$ & $0 \%$ & $5 \%$ \\
\hline 3. & Loss of confidence in fair trial. & 37 & 54 & 5 & 3 & 1 & $37 \%$ & $54 \%$ & $5 \%$ & $3 \%$ & $1 \%$ \\
\hline 4. $\begin{array}{l}\text { Feeling that life is always close } \\
\text { to danger. }\end{array}$ & 35 & 48 & 9 & 4 & 4 & $35 \%$ & $48 \%$ & $9 \%$ & $4 \%$ & $4 \%$ \\
\hline 5. $\begin{array}{l}\text { Considering any effect of } \\
\text { erroneous judgment. }\end{array}$ & 26 & 58 & 9 & 1 & 6 & $26 \%$ & $58 \%$ & $9 \%$ & $1 \%$ & $6 \%$ \\
\hline Justice is for the rich only. & 29 & 44 & 19 & 3 & 5 & $29 \%$ & $44 \%$ & $19 \%$ & $3 \%$ & $5 \%$ \\
\hline
\end{tabular}

Legend:

$\begin{array}{lll}1 & - & \text { Strongly Disagree } \\ 2 & - & \text { Disagree } \\ 3 & - & \text { Neutral }\end{array}$

$\begin{array}{lll}4 & - & \text { Agree } \\ 5 & - & \text { Strongly Agree }\end{array}$

In the foregoing conclusions, the researcher derived that wrongful conviction has a cognitive and emotional impact to the community's perception. It is recommended that possible attitudes of citizens in wrongful conviction should be conducted in an oral interview instead of survey for more specific and defined answer. Additional variables can also be incorporated in the study. Other parameters regarding the behavior of the possible effects of wrongful convictions.

\section{REFERENCES}

[1] Camic, P. M., Rhodes, J. E., \& Yardley, L. E. (2003). Qualitative research in psychology: Expanding perspectives in methodology and design. American Psychological Association.

[2] Cole, S. A. (2006). The prevalence and potential causes of wrongful conviction by fingerprint evidence. Golden Gate UL Rev., 37, 39.

[3] Garoupa, N., \& Rizzolli, M. (2012). Wrongful convictions do lower deterrence. Journal of Institutional and Theoretical Economics (JITE)/Zeitschrift für die gesamte Staatswissenschaft, 224-231.

[4] Findley, K. A. (2001). Learning from our mistakes: A criminal justice commission to study wrongful convictions. Cal. WL Rev., 38, 333.

[5] Huff, C. R., \& Killias, M. (Eds.). (2010). Wrongful conviction: International perspectives on miscarriages of justice. Temple University Press. 
[6] Lando, H. (2006). Does wrongful conviction lower deterrence? The Journal of Legal Studies, 35(2), 327-337.

[7] Leo, R. A., \& Gould, J. (2009). Studying wrongful convictions: Learning from social science. Ohio St. J. Crim. L., 7, 7.

[8] Ramsey, R. J., \& Frank, J. (2007). Wrongful conviction: Perceptions of criminal justice professionals regarding the frequency of wrongful conviction and the extent of system errors. Crime \& Delinquency, 53(3), 436-470.

[9] Risinger, D. M. (2006). Innocents convicted: An empirical justified factual wrongful conviction rate. J. Crim. l. \& Criminology, 97, 761.

[10] Vagias, W. M. (2006). Likert-type scale response anchors. clemson international institute for tourism. \& Research Development, Department of Parks, Recreation and Tourism Management, Clemson University. 